УДК: $352: 332.02$

\author{
Горблюк Сергій, \\ кандидат наук $з$ державного \\ управління, \\ E-mail : s.horbliuk@academy.gov.ua, \\ ORCID Id 0000-0002-5031-2497
}

\title{
ПЕРЕДУМОВИ ТА ЕВОЛЮЦІЯ ВПРОВАДЖЕННЯ ПОЛІТИКИ РЕВІТАЛІЗАЦІЇ МІСТ У НІМЕЧЧИНІ
}

\section{https://doi.org/10.32689/2618-0065-2021-1(7)-83-97}

\begin{abstract}
Анотація. Стаття присвячена встановленню передумов та основних етапів еволюції політики ревіталізації міст у Німеччині. Акцентовано увагу, що в цьому процесі важливе значення відіграє належне та стабільне правове регулювання, а також інституційна пам'ять федеральних урядів, які кардинально не змінювали основні засади політики ревіталізації, а їх удосконалювали. Розглянуто розширення у процесі еволюції німецької політики комплексу інструментів ревіталізації міст від вирішення переважно житлових проблем (знесення, будівництво, модернізація житлового фонду) до забезпечення різноманітної функціональності та максимальної корисності міського простору, проведення “обережної” ревіталізації, зокрема шляхом розвитку унікальної ідентичності здеградованих територій з акцентом на їхній історичній та культурній спадщині. Визначено, що відповідальними за проведення ревіталізації та їі економічні й соціальні наслідки в Німеччині $\epsilon$ місцеві органи публічної влади, втім на ефективність розроблених i впроваджених програм вплинуло широке застосування інструментів громадської партисипації (налагодження тісної комунікації, реалізація “м’яких” проєктів тощо). Виділено новітні тенденції у сфері ревіталізації міст, які стосуються інтегрованих комплексних дій, спрямованих на реструктуризацію здеградованих територій та їх переорієнтацію відповідно до сучасних вимог (програми перебудови міст). При цьому стають все більш важливими питання сталого розвитку, зокрема ресурсоощадність. Запропоновано при розробленні політики ревіталізації міст в Україні врахувати питання державної підтримки й залучення приватного сектора до відповідних заходів, правового регулювання діяльності (насамперед, закріплення відповідальності органів місцевого самоврядування та інструментів партисипації), впровадження комплексу інтегрованих дій, орієнтованих на сталий розвитку здеградованих міських територій тощо.
\end{abstract}

Ключові слова: ревіталізація міста, здеградована територія, Німеччина, зарубіжний досвід, міська політика, сталий розвиток. 
Постановка проблеми. Шлях України до належного забезпечення реалізації глобальних Цілей сталого розвитку [1] вимагає формування дієвих публічних політик у різних сферах життєдіяльності. Однією з ключових $є$ політика розвитку міст. Адже за даними Державної служби статистики України частка міського населення станом на 1 січня 2020 р. у державі становила $69,5 \%$ (без урахування тимчасово окупованої території Автономної Республіки Крим і м. Севастополя) [2]. У свою чергу, важливим інструментом досягнення 11 глобальної цілі “Забезпечення відкритості, безпеки, життєстійкості й екологічної стійкості міст та спільнот" має стати ревіталізація здеградованих міських територій. На відміну від України в економічно розвинених державах становлення публічної політики ревіталізація міст відбувається уже тривалий період. Актуальним для дослідження видається досвід Німеччини. Вона була однією 3 перших держав, які усвідомили необхідність ревіталізації міст та, в підсумку, мають найбільший досвід у цій сфері. Німеччина досягла відчутних результатів у напрямі розбудови міст, що зпоміж іншого дало змогу забезпечити їй лідерство в Європейському Союзі та світі. Проте також були і певні прорахунки в розробці та реалізації такої політики. Їхне уникнення та врахування позитивного досвіду в Україні можливе за умови детального вивчення цих питань.

Аналіз останніх досліджень і публікацій. Ревіталізація $є$ новим напрямом наукових досліджень в Україні. Водночас, він здебільшого розвивається вітчизняними науковцями галузі архітектури. Втім, ця проблематика потребує розроблення 3 позиції науки публічного управління на адміністрування, враховуючи іï міждисциплінарний характер. Вивчення результатів наукових досліджень зарубіжних учених [3-9] та відповідних матеріалів німецьких органів публічної влади [10-11] дозволяє простежити основні аспекти становлення політики ревіталізації міст у Німеччині.

Так, у своїх працях [3; 4] A. Billert окреслив основні зміни в політиці ревіталізації німецьких міст унаслідок деіндустріалізації, демографічних тенденцій та глобалізації. Вони 


\section{Науковий вісник : Державне управління №1 (7) 2021}

призвели до необхідності загальної соціальної та економічної перебудови міст у Німеччині. Тим самим, розробляючи програми ревіталізації міст, протидія небажаним соціально-економічним явищам, таким як соціальна маргіналізація, бідність, безробіття та злочинність у проблемних міських районах знаходиться у фокусі особливої уваги німецьких міст [4, с. 1].

У свою чергу, А. Jadach-Sepioło зазначає, що на початку формування політики ревіталізації міст іiі розглядали як суто фізичну зміну міського простору, а пізніше як процес створення нового життя, посилаючись на функціонування міст з чітким акцентом на економічних функціях [6, с. 28-29]. Утім, відхід від однобічності політики ревіталізації міст (просторовий, економічний, соціальний) та розроблення комплексних інтегрованих заходів відновлення здеградованих міських територій характеризує період кінця XX ст. - поч. ХХІ ст. Враховуючи вищевикладене, питання еволюції політики ревіталізації міст у Німеччині від середини минулого століття до теперішнього часу потребує окремого наукового дослідження, розглядаючи 3-поміж іншого етапи становлення, характерні ознаки та наслідки відповідної політики.

Метою статті $\epsilon$ встановлення передумов та основних етапів еволюції впровадження політики ревіталізації міст у Німеччині, виявлення на цій основі тенденцій та чинників, які слід враховувати при формуванні такої політики в Україні.

Методи дослідження. Для досягнення поставленої мети використовувалися загальнонаукові та спеціальні методи, зокрема: абстрагування, ідеалізація, узагальнення, групування, синтез (визначення передумов формування політики ревіталізації міст у Німеччині); структурно-функціональний, порівняння, аналогія, економіко-статистичний (дослідження еволюції політики ревіталізації німецьких міст); абстрактно-логічний, діалектичний, індукція, прогностичний (теоретичне узагальнення дослідження і формулювання висновків).

Виклад основного матеріалу. Нині німецькі міста $\epsilon$ одними 3 найрозвиненіших у Свропі. Однак вони були i залишаються вразливими до економічних, просторових, 
соціальних та інших загроз розвитку, спричиненими соціальноекономічними змінами (ділові цикли, зростання кількості мігрантів, збільшення частки безробітних тощо).

Слід зазначити, що значний вплив на це мали історичні події. У результаті Другої світової війни майже кожна десяте помешкання у Східній та Західній Німеччині було зруйноване, а кожне сьоме - серйозно пошкоджене. Втім, післявоєнна імміграція (9,5 мільйонів переміщених осіб, біженців та емігрантів зі Сходу) та високий рівень народжуваності спричинили сильний приріст населення [11]. У межах німецького “економічного дива" (Wirtschaftswunder) спостерігалося швидке економічне зростання та розвиток промисловості, при цьому відповідні показники Західної Німеччини були вищими [9, с. 50].

Стрімке зростання населення та початок індустріалізації німецької економіки на рубежі 1950-1960-х рр. активізував проблему дефіциту житлових приміщень. Для іï подолання на околицях міст Західної Німеччини почали розбудовувати житлові комплекси за технологією великої площі, що задовольняло лише основні житлові потреби населення. У Східній Німеччині ситуація була подібною з тією лише різницею, що житлове інвестування зазвичай здійснювалося поблизу розташування промислових об'єктів. Швидке економічне зростання породило значний попит на технічну та соціальну інфраструктуру, яка сильно контрастувала 3 обмеженими просторовими ресурсами тогочасних міст. У підсумку це призвело до хвилі субурбанізації та ослаблення центрів міст. У зв’язку з відсутністю належного правового регулювання політика розвитку німецьких міст набувала все більшої хаотичності. На початку 1960-х рр. у результаті десятирічної праці було розроблено та прийнято федеральний закон про будівництво (Bundesbaugesetz, BBauG). Нові будівельні норми, через поганий технічний стан будівель, були додатковим імпульсом для знесення старих будівель [5, с. 27]. Така політика знесення будівель почала піддаватися все більш різкій соціальній критиці. Це стало початком обговорення засад ревіталізації міст через брак системних вирішень у цій cферi. 


\section{Науковий вісник : Державне управління №1 (7) 2021}

Додатково мали вплив негативні зовнішні наслідки значних обсягів фінансування проєктів ревіталізації 3 федеральних джерел. Вони супроводжувалися низьким інтересом фінансування проєктів 3 боку приватного сектору. Слабкі сторони тодішньої міської політики стали предметом широкої критики з боку урбаністів, міських планувальників і підприємців.

Внаслідок подальших дій у західній Німеччині була розроблена система заходів, відома під назвою “класична німецька модель ревіталізаціі”. Вона грунтувалася на активній участі державного сектора для вирішення місцевих проблем, зокрема шляхом державного субсидування заходів ревіталізації. 3 цією метою в 1971 р. був прийнятий закон про підтримку ревіталізації міст (Staedtebaufoerderungsgesetz), який одночасно передбачав спеціальні державні фонди підтримки (Staedtebaufoerderungsmittel) [3, c. 2]. Прийнятий нормативноправовий акт став основою для подальшої ревіталізації здеградованих міських територій. Так, запроваджувалися прозорі правила розроблення та дієві інструменти фінансування програм ревіталізації (необхідна частка муніципалітету як мінімум 33\%). Завдання щодо ревіталізації міст, зокрема щодо розробки місцевих програм покращення якості міських територій, було віднесено до компетенції органів місцевого самоврядування [5, c. 28]. При проведенні заходів ревіталізації передбачалося надання тимчасового соціального забезпечення населенню, яке проживає в занедбаних районах.

Періодом інтенсивної переорієнтації політики ревіталізації Західної Німеччини стали 70-80-ті pp. минулого століття. Послаблення німецької економіки, викликане глобальними нафтовими кризами, спонукало федеральні органи публічної влади зосередити свої зусилля на відновленні існуючого житла та реконструкції здеградованих центральних районів міст. Розроблені заходи також акцентували уваги на збереженні й розвитку історичних будівель та культурній спадщині, що сприймалися як важливий елемент іміджу міста. Втім, на практиці через відсутність чіткого нормативно-правового регулювання ревіталізаційні проєкти 3 реконструкції та 


\section{Науковий вісник : Державне управління №1 (7) 2021}

будівництва нерідко знищували історично-культурні надбання міських територій. $\mathrm{y}$ рамках ревіталізації міста також реалізовувалися заходи підтримки соціальної інфраструктури, а також торгівлі та послуг на здеградованих територіях.

3 метою запобігання подібним ситуаціям у 1975-1985 pp. у Берліні планувальники сформулювали низку постулатів щодо захисту архітектури та ландшафту відновлюваних районів. Це стало засадничою умовою для програмування відновлення кризових районів на основі обережної ревіталізації (behutsame Stadtsanierung) [7]. Ці постулати згодом були включені до 12 принципів обережної ревіталізації, прийнятих Берлінським парламентом у 1983 р. як своєрідних настанов щодо ревіталізації кризових районів [6, с. 28]. Розроблені рекомендації вказували на необхідність планування ревіталізаційних заходів у співпраці 3 місцевою громадою та їх проведення 3 акцентом на збереження ідентичності міської території.

Наступні роки розширили розуміння соціальних питань у процесі ревіталізації. Внесення поправок до закону про ревіталізацію та впровадження нових регулювань процесу оновлення міст зумовили формування концепції, яка поєднала діяльність, спрямовану на фізичне відновлення міського простору 3 системою соціального забезпечення мешканців та охороною пам'яток. Цей підхід передбачав, що основою будь-яких проєктів ревіталізації має бути суспільний інтерес, тобто поліпшення умов проживання (житло, робота і дозвілля) місцевої громади за рахунок підвищення корисності існуючої інфраструктури та усунення функціональних недоліків міського простору [8, с. 126127]. Досягненню передбачуваних результатів сприяли ухвалені організаційно-правові рішення, зокрема:

обмеження ринкових механізмів і майнових прав на період ревіталізації з метою запобігання спекуляцій та запобігання інвестиціям, які суперечать пріоритетам ревіталізації; забезпечення соціального захисту мешканців ревіталізованих територій;

залучення публічних коштів для фінансування інфраструктурних проєктів ревіталізації, а також підтримки 


\section{Науковий вісник : Державне управління №1 (7) 2021}

приватних інвестицій;

розробка ефективних форм співпраці між органами публічної влади та представниками бізнесу щодо проєктування та реалізації заходів ревіталізації;

впровадження інвестиційних угод, які регулюють масштабні приватні інвестиції відповідно до цілей програм ревіталізації [8, c. 106].

Концепція міської ревіталізації, заснована на вищезазначених принципах, почала широко застосовуватися у Західній Німеччині в другій половині 1980-х рр. Після возз'єднання Німеччини також були зроблені спроби застосувати іiі у східних землях, де питання стійкого розвитку міст було зведено до мінімуму протягом тривалого періоду. На це вплинуло зосередження головним чином на збільшенні житлових ресурсів через неконтрольоване ущільнення існуючих населених пунктів, які не мали належним чином розробленої соціальної інфраструктури, необхідної для підтримки міського характеру цих територій.

Початок 1990-х рр. - це період, коли основною метою політики публічних органів влади стало вирівнювання умов життя на заході та сході держави, та зрештою інтеграція двох різних економік і суспільств [5, с. 21]. Як наслідок, більшість публічних коштів, виділених на ревіталізацію, були направлені в здеградовані райони Східної Німеччини. Вони спрямовувалися на подолання кризових явищ, таких як економічна рецесія, різке зростання безробіття та пов'язана 3 цим еміграція населення до західних земель, деградація житла та скорочення населення міст. Ці та інші проблеми спричинили зміни у просторовій та функціональній структурі міських центрів, погіршили їх імідж та послабили інтерес потенційних інвесторів. Масштаби деградаційних процесів у містах Східної Німеччини були настільки великі, що класичної моделі ревіталізації було недостатньо для їх ефективного подолання.

Кризові явища, спричинені наслідками деіндустріалізації та глобалізації, спричинили необхідність вдосконалення програм ревіталізації. Обмежена ефективність тодішніх стратегій оновлення міських просторів стала імпульсом для розробки 
нових ініціатив, що забезпечували ревіталізацію. Особлива увага приділялася інтеграції місцевої спільноти до вирішення соціальних проблем на здеградованих територіях і забезпечення поєднання заходів соціального характеру 3 фізичним відродженням міського простору.

Такий підхід вкінці 1990-х рp. призвів до запуску загальнонаціональної програми "Міські квартали 3 особливим попитом на ревіталізацію" (Stadtteile mit besonderem Erneuerungsbedarf - die soziale Stadt) (Соціальне місто) [6, с. 31]. Ïї реалізація стала відповіддю на зростаючу соціальну сегрегацію і концентрацію бідного населення в окремих районах німецьких міст. Це стало початком так званої суспільної ревіталізації. У свою чергу федеральний уряд фінансово підтримав модернізацію міських, економічно та соціально незахищених, структурно слабких міських здеградованих територій на засадах громадської партисипації. До заходів ревіталізації почали включати фінансування не лише проєктів будівництва та інфраструктури, а й “м'які" соціальні проєкти (підвищення рівня освіти та професійної кваліфікації мешканців здеградованих міських територій) [5, с. 35]. Водночас 3 ревіталізацією соціального характеру розвивалася ревіталізація на основі класичної моделі, орієнтованої на поліпшення якості житлового середовища, збереження історичних будівель, догляд за естетикою міських просторів тощо. Згодом каталог зазначених інструментів розширився, включивши в себе поняття спеціальних міських зон, які служать для економічної активізації розвитку занедбаних територій $[5$, с. $78-81]$.

Водночас набуває актуальності тогочасна проблема опустошення житлових площ на окремих міських територіях. Так, наприкінці 2000 р. у Східній Німеччині через міграцію та зниження чисельності населення налічувалося близько мільйона вакантних квартир. Окремі міста Західної Німеччини також все більше зазнавали негативних демографічних тенденцій та економічних структурних змін. Для вирішення зазначених проблем розроблялися заходи перепланування міста, зокрема модернізації житлових районів, знесення невикористовуваних 


\section{Науковий вісник : Державне управління №1 (7) 2021}

об'єктів, а також розробки інтегрованих концепцій розвитку здеградованих територій.

У свою чергу, концепція ревіталізації міста все більше почала орієнтуватися на інтегрований розвиток міст на засадах сталого розвитку. 3 цією метою починають впроваджуватися програми "Перебудова міста" (Stadtumbau), які спочатку окремо розробляються для Східної та Західної частин держави (Stadtumbau Ost та Stadtumbau West) [10]. При цьому структурне перепланування передбачало забезпечення рівноваги на ринку житла, зміцнення соціальної згуртованості та забезпечення екологічної самодостатності, економічної стабільності й упровадження культурних інновацій. Екологічні проблеми, зокрема захист та адаптація до зміни клімату, стають все більш важливими орієнтирами при проведенні ревіталізації.

Програми перебудови міст були фінансово підтримані федеральним урядом та реалізовані муніципалітетами. У 2010 р. за рішенням німецького Бундестагу розпочався другий період фінансування, який тривав до 2016 р. Заходи з реструктуризації міст були профінансовані у 1024 муніципалітетах за обома програмами: 494 муніципалітети на східній міській ревіталізації, 530 муніципалітетів у західній міській ревіталізації. В 2017 р. програми міського перепланування Схід та Захід були об'єднані у спільну програму перебудови міст [10]. Важливу роль при цьому відіграє прагнення до соціальної активізації та посилення ідентифікації мешканців 3 містом шляхом розвитку самоврядування та суспільної партиципації. У цій ситуації публічний сектор забезпечує координацію дій, впроваджуючи дієві інструменти співробітництва 3 приватним та громадським. Еволюція підходів до ревіталізації в Німеччині від 1960-х рр. до сучасного періоду зображено в табл. 1. 


\section{Таблиця 1 - Еволюція німецької політики ревіталізації міст*}

\begin{tabular}{|c|c|c|c|}
\hline & апи еволюції & Характерні ознаки & Наслідки \\
\hline 1 & $\begin{array}{c}\text { Початковий етап } \\
\text { становлення } \\
\text { ревіталізації (1961- } \\
1971 \text { рр.) }\end{array}$ & $\begin{array}{l}\text { Старі житлові будівлі були } \\
\text { замінені на нові, які відповідали } \\
\text { будівельним нормам. } \\
\text { Роботи зі знесення повністю } \\
\text { фінансувалися за } \\
\text { федеральних коштів. } \\
\text { Прийнято федеральний закон про } \\
\text { будівництво. }\end{array}$ & 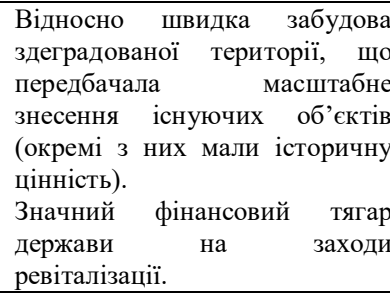 \\
\hline 2 & $\begin{array}{c}\text { Криза системи } \\
\text { фінансування в } \\
\text { початковій моделі } \\
\text { ревіталізації } \\
\text { (початок } 1970-x \text { рр.) }\end{array}$ & $\begin{array}{l}\text { Власники майна } \\
\text { вкладати свої приватні ресурси у } \\
\text { сфери ревіталізації. Це призвело } \\
\text { до значного } \\
\text { житлових уогіршення } \\
\text { будівель, нев у більшості } \\
\text { ревіталізацісю, та втечі кращих } \\
\text { орендарів в інші райони. } \\
\end{array}$ & $\begin{array}{lr}\text { Трансформація } & \text { системи } \\
\text { загального } & \text { фінансування } \\
\text { ревіталізації з } & \text { федеральних } \\
\text { фондів у } & \text { державне } \\
\text { субсидування } & \text { заходів } \\
\text { ревіталізації. } & \end{array}$ \\
\hline 3 & $\begin{array}{c}\text { Формування } \\
\text { класичної німецької } \\
\text { моделі ревіталізації, } \\
\text { 1970-ті, поч. 1980-х } \\
\text { рр. }\end{array}$ & 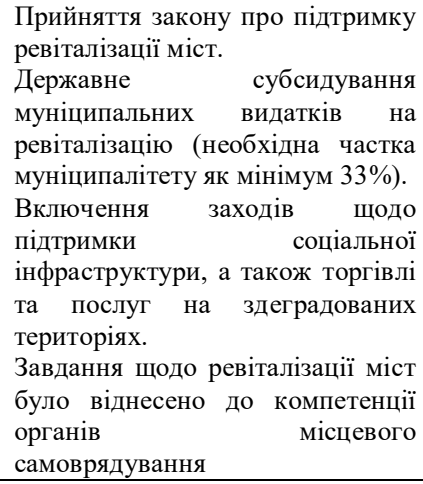 & $\begin{array}{l}\text { Вдосконалення правової бази } \\
\text { щодо ревіталізації та } \\
\text { державних фондів підтримки. } \\
\text { Зміна підходу до ревіталізації, } \\
\text { зокрема } 4 \text { врахування } \\
\text { соціальних, ландшафтних та } \\
\text { культурних аспектів при } \\
\text { проведенні ревіталізації (на } \\
\text { практиці ці зміни } \\
\text { впроваджувалися повільно) } \\
\text { Налагодження співпраці між } \\
\text { публічним та приватним } \\
\text { секторами. }\end{array}$ \\
\hline 4 & $\begin{array}{c}\text { Перехід до } \\
\text { обережної } \\
\text { ревіталізації } \\
\text { (вдосконалення } \\
\text { класичної німецької } \\
\text { моделі ревіталізації), } \\
\text { 1980-ті рр. }\end{array}$ & 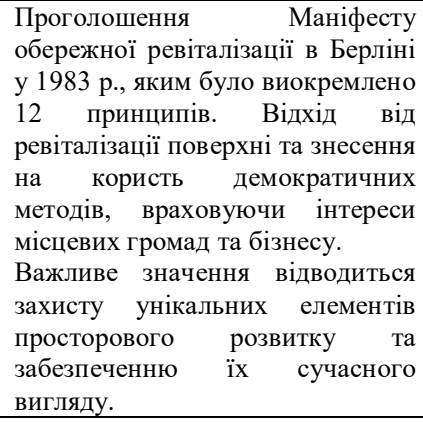 & 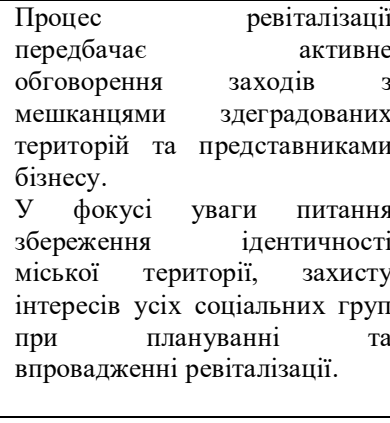 \\
\hline 5 & $\begin{array}{c}\text { Суспільна } \\
\text { ревіталізація, кінець } \\
\text { 1990-х рр. }\end{array}$ & $\begin{array}{l}\text { Впровадження програми “Міські } \\
\text { квартали } 3\end{array}$ & $\begin{array}{l}\text { Впровадження інтегрованих } \\
\text { програм ревіталізації. Активна } \\
\text { участь мешканців у розробці та } \\
\text { впровадженні ревіталізації. } \\
\text { Включення “м'яких" проєктів } \\
\text { до заходів ревіталізаціі }\end{array}$ \\
\hline
\end{tabular}


Науковий вісник : Державне управління №1 (7) 2021

\begin{tabular}{|c|c|c|c|}
\hline & Етапи еволюції & Характерні ознаки & Наслідки \\
\hline & & $\begin{array}{lcr}\text { Намагання } & \text { забезпечити } \\
\text { поєднання } & \text { заходів } & \text { соціального } \\
\text { характеру } & 3 & \text { фізичним } \\
\text { оновленням } & \text { міського простору. } \\
\text { Характерною } & \text { особливістю } \\
\text { програм ревіталізації стає } \\
\text { фінансування “м’яких” проєктів. }\end{array}$ & \begin{tabular}{lr}
\multicolumn{2}{l}{ (насамперед, підвищення рівня } \\
освіти та & професійної \\
кваліфікації & мешканців \\
здеградованих & міських \\
територій). &
\end{tabular} \\
\hline 6 & $\begin{array}{c}\text { Ревіталізація в } \\
\text { інтегрованій } \\
\text { перебудові } \\
\text { німецьких міст, } \\
\text { перше та друге } \\
\text { десятиліття XXI ст. }\end{array}$ & $\begin{array}{lr}\text { Впровадження } & \text { програм } \\
\text { “Перебудова } & \text { міста”, } \text { фінансово } \\
\text { підтриманих } & \text { федеральним } \\
\text { урядом. Заходи } & \text { реорганізаціъ } \\
\text { міського простору, визначення } \\
\text { інвестиційних } & \text { пріоритетів та } \\
\text { проведення } & \text { реструктуризації } \\
\text { здеградованих } & \text { територій. } \\
\text { Врахування } & \text { екологічних } \\
\text { аспектів. }\end{array}$ & $\begin{array}{l}\text { Ревіталізація як інструмент } \\
\text { інтегрованої міської політики. } \\
\text { Проєктування } \\
\text { міських територій відбувається } \\
\text { у напрямі забезпечення } \\
\text { рівноваги на ринку житла } \\
\text { відповідно до вимог сталого, } \\
\text { ресурсозберігаючого міського } \\
\text { розвитку. }\end{array}$ \\
\hline
\end{tabular}

*складено автором за результатами $[4 ; 5 ; 7 ; 9]$.

В останні роки німецькі міста зазнають відчутної поляризації. Так, набувають розвитку великі мегаполіси та райони економічного зростання (насамперед, на півдні та заході держави). Разом з тим, поширені соціальні та житлові проблеми в зв'язку 3 приїздом у Німеччину понад мільйона мігрантів [4, с. 47-48]. Не можна виключати, що ці диспропорції будуть i надалі посилюватися. Вищевикладене спричинить метрополізацію одних міст і периферійність інших 3 усіма соціальними, економічними та екологічними наслідками, незважаючи на поліпшення рівня життя у містах, дотації держави та $\mathrm{EC}$, а також значні приватні інвестиції. Разом 3 тим, це вимагатиме подальшого перегляду підходів до ревіталізації німецьких міст.

Висновки та перспективи подальших досліджень. Отже, протягом досліджуваного періоду Німеччині вдалося запровадити та вдосконалити відповідно до вимог часу “німецьку модель ревіталізації, яка в 90-х рp. минулого століття збагатилася практикою вирішення проблем здеградованих територій східнонімецьких міст. Проведене дослідження еволюції становлення основних засад ревіталізації міст у Німеччині дозволяє виокремити такі тенденції та чинники: 
1) від початку застосування ревіталізації (1960-ті рр.) Західна Німмечина виділяла значні кошти з федерального бюджету на ці цілі, проте кращих результатів вдалося досягти після усвідомлення необхідності захисту інтересів приватного сектору в цьому процесі та формування дієвих механізмів залучення фінансових ресурсів з різних джерел;

2) на успішність ревіталізаційної діяльності впливає належне та стабільне правове регулювання ревіталізації (у 1971 р. прийнято рамковий закон та в подальшому відбулося лише кілька відповідних законодавчих змін протягом усього періоду), а також інституційна пам'ять федеральних урядів, які кардинально не змінювали засади політики ревіталізації, а їх удосконалювали;

3) найголовніше в німецькій політиці ревіталізації міст прагнення повернути занедбаним міським територіям привабливість для проживання, що в процесі еволюції політики зумовило поступове розширення комплексу інструментів ревіталізації від вирішення переважно житлових проблем (знесення, будівництво, модернізація житлового фонду) до забезпечення різноманітної функціональності та максимальної корисності міського простору, проведення “обережної" ревіталізації, зокрема шляхом розвитку унікальної ідентичності здеградованих територій 3 акцентом на їхній історичній та культурній спадщині (1980-ті рр.);

4) відповідальними за проведення ревіталізації та іiі економічні й соціальні наслідки є місцеві органи публічної влади, втім на ефективність розроблених і впроваджених програм вплинуло широке застосування інструментів громадської партисипації (налагодження тісної комунікації, реалізація “м'яких" проєктів тощо); в підсумку модель ревіталізації набула чітко вираженого суспільного характеру (1990-ті рр.);

5) новітні тенденції у сфері ревіталізації міст стосуються інтегрованих комплексних дій, які спрямовані на реструктуризацію здеградованих територій та їх переорієнтацію відповідно до сучасних вимог (програми перебудови міст); при цьому питання сталого розвитку, такі як: ресурсоощадність, захист клімату та адаптація до відповідних змін, стають все більш 


\section{Науковий вісник : Державне управління №1 (7) 2021}

важливими для житлового будівництва, розбудови публічних просторів й інфраструктури (від 2000-х рр. до сьогодення).

3 огляду на проаналізований німецький досвід в Україні при розробленні політики ревіталізації міст слід врахувати питання державної підтримки й залучення приватного сектора до відповідних заходів, правового регулювання діяльності (насамперед, закріплення відповідальності органів місцевого самоврядування та інструментів партисипації), обгрунтування комплексу інтегрованих дій, орієнтованих на сталий розвиток здеградованих міських територій тощо. Це стане предметом подальших наукових досліджень.

\section{Список використаних джерел}

1. Про Цілі сталого розвитку України на період до 2030 року : Указ Президента України від 30.09.2019 р. № 722/2019. URL : https://zakon.rada.gov.ua/laws/show/722/2019 (дата звернення 01.12.2020).

2. Чисельність наявного населення України на 1 січня 2020 року / Державна служба статистики України. URL : https://cutt.ly/vkH6Zeb (дата звернення : 01.12.2020).

3. Billert A. Problemy rewitalizacji w Polsce na tle doświadczeń niemieckich. Referat wygłoszony na Międzynarodowej Konferencji w Lubaniu Śląskim "Rewitalizacja miast". URL : https://cutt.ly/YkH620x (дата звернення : 02.12.2020).

4. Billert A. Rewitalizacja miast jako program publiczny na przykładzie niemiec w latach 1971-2000. Rocznik Lubuski. 2019. T. 45, cz. 2. S. 37 50.

5. Bryx M., Jadach-Sepioło A. Rewitalizacja miast w Niemczech. Rewitalizacja Miast Polskich, T. 3. Kraków: Instytut Rozwoju Miast, 2009. 304 s.

6. Jadach-Sepioło A. Rafy procesu rewitalizacji - teoria i polskie doświadczenia. Gospodarka w praktyce i teorii. 2018 . №49 (4). S. 23 39.

7. Monheim H. Stadterneuerung in Kleinund Mittelstädten. Ein Plädoyer für die Behutsamkeit. Informationen zur Raumentwicklung Bonn-Bad Godesberg. 1985. № 9. S. $833-839$.

8. Podręcznik rewitalizacji. Zasady, procedury i metody działania współczesnych procesów rewitalizacyjnych / I. Behr, A. Billert, W. Kroning \& A. Muzioł-Węcławowicz. Warszawa, 2003. 144 s. 
9. Sleifer J. Planning Ahead and Falling Behind: The East German Economy in Comparison with West Germany, 1936-2002. Berlin: Akademie Verlag, 2006. $239 \mathrm{p}$.

10. Bundesministerium des Innern, für Bau und Heimat. Stadtumbau. URL : https://cutt.ly/1kJqpwx (дата звернення 02.12.2020).

11. Statistisches Jahrbuch 2000 für die Bundesrepublik Deutschland. Statistisches Bundesamt. 2000. 763 s.

\section{References}

1. Pro Tsili staloho rozvytku Ukrainy na period do 2030 roku : Ukaz Prezydenta Ukrainy vid 30 veresnia 2019 roku № 722/2019 [Decree of the President of Ukraine "On the Sustainable Development Goals of Ukraine until 2030" from 30.09.2019]. (2019). Retrieved from https://zakon.rada.gov.ua/laws/main/2147-19 [in Ukrainian].

2. Chyselnist naiavnoho naselennia Ukrainy na 1 sichnia 2020 roku, Derzhavna sluzhba statystyky Ukrainy 「Number of existing population of Ukraine as of January 1, 2020, State Statistics Service of Ukrainel. (2020). Retrieved from http://www.ukrstat.gov.ua/druk/publicat/kat_u/2020/zb/05/zb_chuselnist \%202019.pdf [in Ukrainian].

3. Billert, A. Problemy rewitalizacji w Polsce na tle doświadczeń niemieckich. Retrieved from https://cutt.ly/9kJqbE2 [in Polish].

4. Billert, A. (2019). Rewitalizacja miast jako program publiczny na przykładzie Niemiec w latach 1971-2000. Rocznik Lubuski, 45(2), 37-50 [in Polish].

5. Bryx, M., \& Jadach-Sepioło, A. (2009). Rewitalizacja miast $w$ Niemczech. Rewitalizacja Miast Polskich, 3. Kraków: Instytut Rozwoju Miast [in Polish].

6. Jadach-Sepioło, A. (2018). Rafy procesu rewitalizacji - teoria i polskie doświadczenia. Gospodarka w praktyce i teorii, 49(4), 23-39 [in Polish].

7. Monheim, H. (1985). Stadterneuerung in Klein-und Mittelstädten. Ein Plädoyer für die Behutsamkeit. Informationen zur Raumentwicklung Bonn-Bad Godesberg, (9), 833-839 [in German].

8. Behr, I., Billert, A., Kroning, W., \& Muzioł-Wẹcławowicz, A. (2003). Podrecznik rewitalizacii. Zasady, procedury $i$ metody działania współczesnych procesów rewitalizacii. Warszawa [in Polish].

9. Sleifer, J. (2006). Planning Ahead and Falling Behind: The East German Economy in Comparison with West Germany, 1936-2002, Berlin: Akademie Verlag [in English].

10. Bundesministerium des Innern, für Bau und Heimat (2017). Stadtumbau. Retrieved from https://cutt.ly/ykJqOdx [in German].

11. Statistisches Bundesamt (2000). Statistisches Jahrbuch 2000 für die Bundesrepublik Deutschland [in German]. 


\title{
BACKGROUND AND EVOLUTION OF URBAN REVITALIZATION POLICY IN GERMANY
}

\section{Horbliuk Serhii}

\begin{abstract}
The article is dedicated to establishing the preconditions and main stages of the urban revitalization policy evolution in Germany. It emphasizes that proper and stable legal regulation plays in this process an important role, as well as the institutional memory of federal governments, which have not changed radically the basic principles of revitalization policy but have improved them.

Under consideration was the expansion in the process of German policy evolution of urban revitalization tools set from solving mainly housing problems (demolition, construction, modernization of housing stock) to providing various functionality and maximal urban space usefulness, implementation of "careful" revitalization, in particular by developing a unique identity of degraded areas with emphasis on their historical and cultural heritage.

The paper determines that local public authorities are responsible for revitalization and its economic and social consequences in Germany, but the effectiveness of developed and implemented programs has been influenced by the widespread use of public participation tools (establishing close communication, implementing "soft" projects, etc.).

The latest trends in the field of urban revitalization are singled out, which concern the integrated complex actions, directed to restructuring degraded areas and their reorientation according to modern requirements (urban restructuring programs). Therefore, issues of sustainable development, in particular resource efficiency, are becoming increasingly important.

When developing the urban revitalization policy in Ukraine the paper proposes to take into account the issues of state support and involvement of the private sector in appropriate measures, legal regulation of activity (first of all, fixing of local governments responsibility and participation tools), implementation of integrated actions complex aimed at sustainable development of degraded urban areas, etc.
\end{abstract}

Keywords: urban revitalization, degraded territory, Germany, foreign experience, urban policy, sustainable development. 